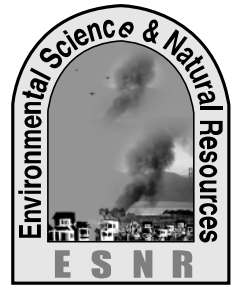

J. Environ. Sci. \& Natural Resources, 5(2): 219 - 224,2012

ISSN 1999-7361

\title{
Effect of Organic Farming on Nutrient Uptake and Quality of Potato
}

\author{
M. R. Islam ${ }^{1}$ and B. S. Nahar ${ }^{2}$ \\ ${ }^{1}$ Department of Environmental Science, ${ }^{2}$ Center for Environmental Studies \\ Bangladesh Agricultural University, Mymensingh
}

\begin{abstract}
The experiment was carried out at the Environmental Science Field Laboratory, Bangladesh Agricultural University, Mymensingh during the period November 2004 to February 2005 to evaluate the effect of organic farming on soil and potato quality. The experiment was laid out in a randomized complete Block Design with five treatment and three replications. The treatments and their combinations were cowdung, poultry manure, inorganic fertilizer, cowdung plus inorganic fertilizer and poultry manure plus inorganic fertilizer. The nutrient content of $\mathrm{P}, \mathrm{K}, \mathrm{Ca}, \mathrm{Mg}, \mathrm{Zn}$ of tuber and haulm, and starch and protein content in tuber were highest in cowdung treated potato and but $\mathrm{N}$ and $\mathrm{S}$ content of both tuber and haulm were highest in case of poultry manure. The uptake of $\mathrm{P}, \mathrm{K}, \mathrm{Mg}$ and $\mathrm{S}$ of both tuber and haulm in case of poultry manure but $\mathrm{N}$ and Zn uptake was highest in case of poultry manure plus inorganic fertilizer. Finally, calcium uptake was highest in cowdung in both cases of tuber and protean and starch contents were influenced by organic farming.
\end{abstract}

Key word: Nutrient content, Organic farming, Potato, Quality

\section{Introduction}

Potato (Solanum tuberosum L.) belongs to Solanaceae family. It is the world leading vegetable crop along with the cheapest source of carbohydrates and furnishes appreciable amount of vitamin $\mathrm{B}$ and $\mathrm{C}$ as well as some minerals (Thompson and Kelley, 1972). Potato is well known for highest food value in the world. As a starchy food, it has more energy value, protein and minerals in comparison to other vegetables and root crops. It has fair amount of vitamin A (which is generally lacking in cereal foods), which is essential for proper growth and development of human body. The importance of potato as vegetables in our diet is well known. Potato is common vegetable used in our every day mill. It has the highest food value on a dry matter basis and it is also the most nutritious in proportion to its calorie value (Khurana, 1978). It is considered as the staple food in about 40 countries of the world. Potato has acquired great importance in rural economy in Bangladesh. It is not only a cash crop but also a substitute of food crop next to rice and wheat.

Fertilizers are essential part of modern farming, with about $50 \%$ of the world's production being attributed to fertilizer use. Nevertheless, it is true that fertilizers might be a source of the environmental degradation of soil. Intensive use of chemical fertilizers can jeopardize the conservation of soil and invites some new problems, which may create potential health hazards (Pradhan, 1992).

Conversion from commercial fertilizer (conventional farming) to organic farming causes changes in the soil other than the fertility effects that can affect plant growth (Power and Doran, 1984; Scow et al., 1994; Drinkwater et al., 1995). The principle aims of organic farming as expressed in the recent version
(IFOAM, 1996) are (i) to produce food of high nutritional qualities (ii) to maintain and increase long term fertility of soil and (iii) to minimize all forms of pollution that may results from agricultural practices. From the previous report (Islam et al., 2008) it is clear that the combination of organic matter with conventional farming showed its superiority on yield and yield contributing characters of potato. Moreover, there is little information on the effect of organic farming on soil and potato quality and yield production of potato in the world even in Bangladesh (IFOAM, 1996).

In accordance of consideration of the above-discussed factors, the present study was undertaken with the following objectives:

1) To find out the interaction effect between conventional and organic farming on potato quality

2) To assess the nutritive quality of potato tuber

\section{Material and Methods}

\section{Soil of the experimental Field}

The soil of the experimental field belongs to the Sonatola soil series of non -calcareous, dark grey under the Old Brahmaputra Alluvial Tract, which is more or less neutral in reaction. The experimental field was a medium high land with leveled topography and poor drainage condition. Physical characteristics, the physical and chemical status of soil of the experimental field have been shown in Table 1. 


\section{Land Preparation}

The experimental field was first opened in the October 2004 with a tractor and was exposed to the sunlight for seven days prior to next ploughing. The land was then harrowed, ploughed and crossploughed several times with a power tiller followed by laddering to obtain a good tilt. Then the land was leveled, weed, stubbles, and crop residues were removed and the land was then finally prepared four days before planting the seed tubers.

\section{Layout and Design of the Experiment}

The experiment was laid out in Randomized Complete Block Design with three replications. The total numbers of unit plots were 15 . The size of an unit plot was $2.0 \mathrm{~m} \mathrm{X} 2.0 \mathrm{~m}$. Inter-block and interplot spacing were $1.0 \mathrm{~m}$ and $0.50 \mathrm{~m}$ respectively.

\section{Treatments of the Investigation}

The experiment was conducted with five treatments viz. conventional farming (inorganic fertilizer), cowdung, poultry manure, cowdung plus recommended fertilizer and poultry manure plus recommended fertilizer. Cowdung and poultry manure were as the source of organic farming and the combinations (Cowdung + conventional farming and poultry manure + conventional farming) as the source of interaction between conventional and organic farming. The treatments used for the experiment were as follows: i) $T_{1}=$ Cowdung @ $30 \mathrm{t} / \mathrm{ha}$, ii) $\mathrm{T}_{2}=$ Poultry manure@25 t/ha, iii) $\mathrm{T}_{3:=}=$ Conventional farming (inorganic fertilizer) @ $250 \mathrm{Kg}$ urea/ha, $220 \mathrm{Kg} \mathrm{TSP} / \mathrm{ha}, 250 \mathrm{Kg} \mathrm{MP} / \mathrm{ha}, 120 \mathrm{~kg}$ gypsum$/ \mathrm{ha}$ and $10 \mathrm{Kg}$ Zinc Sulphat/ha

iv) $\mathrm{T}_{4}=$ Cowdung + conventional farming $(50 \%$ cowdung \& $50 \%$ inorganic of the above recommendation)

v) $\mathrm{T}_{5}=$ Poultry manure + conventional farming $(50 \%$ cowdung \& $50 \%$ inorganic of the above recommendation)

\section{Preparation of Seed materials}

The seed potatoes of the variety (Solanum tuberosum L.) cv. Diamont Diamont were collected from Bangladesh Agricultural Development Corporation (BADC). Ten days before planting, seed potatoes were kept in defused light in order to obtained healthy and good sprouts. Well sprouted whole seed tubers were cut into pieces maintaining 4-5 eyes per piece. The average weight of the cut seed piece was recorded to be $20 \mathrm{~g}$.

\section{Planting of seed Tubers}

The seed tubers were planted in 30 November 2004 in rows in Furrows made with the help of the country plough. The unit plot size was $2.0 \mathrm{~m}$ X $2.0 \mathrm{~m}$ and the seed tubers were planted in furrows at a distance of $60 \mathrm{~cm}$ from row to row and $20 \mathrm{~cm}$ from tuber to tuber. The depth of the planting was approximately 7 $\mathrm{cm}$. Immediate after planting the seed tubers were covered with soil.

\section{Intercultural Operations}

Manual weeding was done as and when necessary to keep the plots free from weeds. The soil was mulched by breaking the crust for an easy aeration and to conserve soil moisture. Earthing up was done twice during the growing period of the potato tubers. The first earthing up was done at 25 days after planting. The second and the final earthing up were done at 45 days after planting, which was preceded by top dressing of the remaining Urea and MP fertilizer.

\section{Analytical methods}

Plant samples were collected from the field experiment to analyze the $\mathrm{N}, \mathrm{P}, \mathrm{K}, \mathrm{Ca}, \mathrm{Mg}, \mathrm{S} \& \mathrm{Zn}$ content of tuber and haulm and protein and starch content of potato tuber. The tuber and haulm samples were dried in an oven at about $65^{\circ} \mathrm{C}$ of 48 hours and then ground in a grinding machine to pass through a 20 mesh sieve. The ground plant materials (tuber and haulm) were stored in a small paper bags and placed in a desicator. The methods for plant analysis were as follows:

Digestion of plant samples with Nitric-Perchloric acid in 2:1 ratio

An amount of $1 \mathrm{~g}$ oven-dried, ground samples were taken in a $150 \mathrm{ml}$ Kjeldahl flask. Five $\mathrm{ml}$ nitric acid was added into the flask and the flasks were allowed and stand for about 24 hours. Then $2.5 \mathrm{ml}$ perchloric acid was added into the flask and followed by heating to boiling. Heating was continued until the digest was clear and colorless. After cooling, the content was transferred to a $50 \mathrm{ml}$ volumetric flask and the volume was made up to the mark with distilled water and the extracts were collected separately in polyvinyl vials. A reagent blank was prepared in the similar manner. This extract was performed for $\mathrm{P}, \mathrm{K}, \mathrm{Ca}, \mathrm{Mg}$, $\mathrm{Zn}$ and $\mathrm{S}$ determination. The total nitrogen content of plant samples were determined by Micro-Kjeldahl method (Page et al., 1989). Phosphorus was estimated from the digest by using spectrophotometer after developing yellow color with Barton solution as described by Jackson (1973). Potassium was measured by using atomic absorption spectrophotometer at $766.6 \mathrm{~nm}$ wavelength (Page et al., 1989). Sulphur content in the digest was determined by adding acid seed solution and then turbidimetric solution and measuring the turbidity by spectrophotometer at $535 \mathrm{~nm}$ wavelength (Hunter, 1984). Zinc content of the digest was determined 
directly by atomic absorption spectrophotometer (Page et al., 1989). Calcium and Magnesium content in the digest were determined directly by atomic absorption spectrophotometer (Page et al., 1989).

\section{Protein content of tuber}

The total nitrogen of the samples was determined by Kjeldahl apparatus as described by Jackson (1973). Then the percentage of protein in tuber was calculated by multiplying the factor 5.88 (Morrison, 1956).

$\%$ protein $=\% \mathrm{~N} \times 5.88$

\section{Starch content of tuber}

One gram of oven dried and desiccated powdered sample was taken in an Erlenmeyer flask and $50 \mathrm{~mL}$ of cold water was added. The content of flask was allowed to stand for one hour with occasional stirring. It was then filtered and the residue was washed with $50 \mathrm{~mL}$ distilled water. The sample was hydrolyzed with $10 \%(50 \mathrm{~mL}) \mathrm{HCl}$ for 2.5 hours under reflux. The hydrolysis was neutralized with dilute $\mathrm{NaOH}$ solution and filtered. The filtrate was collected in a $100 \mathrm{~mL}$ volumetric flask and volume was made upto $100 \mathrm{~mL}$.

\section{Preparation of Fehling's solution 1 and 2 Fehling's solution-1}

$34.64 \mathrm{~g}$ of A.R. crystalline $\mathrm{CuSO}_{4}$ was dissolved in $500 \mathrm{~mL}$ water.

Fehling's solution- 2

$173 \mathrm{~g}$ of Rochelle's salt (Sodium Potassium Tartarate) and $125 \mathrm{~g} \mathrm{NaOH}$ ware dissolved in $500 \mathrm{~mL}$ water in a volumetric flask.

\section{Standard glucose solution preparation}

One g of pure glucose was dissolved in $100 \mathrm{~mL}$ distilled water. When fehling's was required, equal volume of solution 1 and 2 was transferred to a dry flask and mixed thoroughly.

Five $\mathrm{mL}$ mixed fehling's solution was taken in a beaker. Diluted with 15 to $20 \mathrm{~mL}$ water, heated to boiling and added unknown glucose solution from the burette drop by drop until the colour of the solution was about to disappear. Two to three drops methylene blue indicator was added. The titration was completed until the color of the methylene blue just disappeared. The same procedure was followed using the standard glucose solution and the percent (\%) of glucose was calculated. Percentage of starch was calculated from the following relationship-

$$
\% \text { Starch }=\% \text { Glucose } \times 0.90
$$

\section{Nutrients Uptake}

The uptake of nutrients was calculated by multiplying the concentration of the nutrients in the tuber and haulm samples with the corresponding yields of tuber and haulm of the potato.

$$
\begin{aligned}
& \text { Yield (tuber/haulm) } \mathrm{Kg} \mathrm{ha}^{-1} \times \\
& \% \text { nutrient conc. }
\end{aligned}
$$

Nutrients Uptake $\left(\mathrm{Kg} \mathrm{ha}^{-1}\right)=\frac{100}{100}$

\section{Statistical analysis}

The collected data were compiled and tabulated in proper form and were subjected to statistical analysis by F-test to examine the treatment effects. The analysis of variance was done following the computer package MSTAT. The mean differences were adjudged by Duncan's Multiple Range Test (DMRT) and ranking was indicated by letters (Gomez and Gomez, 1984).

\section{Results and Discussion}

\section{Nitrogen Uptake by potato}

Table 1 and 2 showed that nitrogen uptake by potato tuber and haulm was significantly influenced by different treatments. The highest and lowest nitrogen uptake by tuber and haulm were found to be similar due to different treatments effect.The $\mathrm{N}$ uptake by potato tuber varied from 297.29 to $628.68 \mathrm{~kg} \mathrm{ha}^{-1}$. The highest $\mathrm{N}\left(628.68 \mathrm{~kg} \mathrm{ha}^{-1}\right)$ uptake by tuber was found in the treatment of where cowdung was applied $\left(\mathrm{T}_{1}\right)$ and the lowest uptake was recorded where inorganic fertilizer was used $\left(\mathrm{T}_{3}\right)$ (Table 1$)$. The nitrogen uptake by potato haulm varied from 13.81 to $39.50 \mathrm{~kg} \mathrm{ha}^{-1}$ (Table 2). The maximum $\mathrm{N}$ uptake (39.50 kg ha ${ }^{-1}$ ) haulm was found where poultry manure was used in combination with inorganic fertilizer $\left(\mathrm{T}_{3}\right)$ and the lowest $\left(13.81 \mathrm{~kg} \mathrm{ha}^{-1}\right)$ was found in the treatment of inorganic fertilizer $\left(\mathrm{T}_{3}\right)$. This result might be due to higher $\mathrm{N}$ content in both potato tuber and haulm. Senger et al. (2000) and Sharma et al. (2000) observed that the application of $\mathrm{N}$ fertilizer and manure significantly influenced the $\mathrm{N}$ uptake by rice plant.

\section{Phosphorus Upatke}

There was a significant variation in phosphorus uptake by potato tuber and haulm (Table $1 \& 2$ ). Phosphorus uptake by potato tuber ranged from 71.61 to $211.67 \mathrm{~kg} \mathrm{ha}^{-1}$. The maximum Phosphorus uptake by potato tuber $\left(211.67 \mathrm{Kg} \mathrm{ha}^{-1}\right)$ was observed where poultry manure was used individually $\left(\mathrm{T}_{2}\right)$ and the minimum (71.61 $\mathrm{Kg} \mathrm{ha}^{-1}$ ) was recorded in the interaction of poultry manure and conventional farming $\left(\mathrm{T}_{3}\right)$ (Table 1). The phosphorus uptake by potato haulm ranged from 2.67 to $8.74 \mathrm{~kg} \mathrm{ha}^{-1}$ (Table 2). The maximum phosphorus uptake by potato haulm $\left(8.74 \mathrm{~kg} \mathrm{ha}^{-1}\right)$ was found where poultry manure was used individually $\left(\mathrm{T}_{2}\right)$ and the lowest was found in case of conventional farming $\left(T_{3}\right)$ (Table 2$)$. The 
interaction between organic and conventional farming showed an increasing effect on phosphorus uptake by potato tuber and haulm. Brahmachari and Mandal (2000) reported that NPK uptake by rice was recorded maximum under the FYM + NPK treatment compared with control.

\section{Potassium Uptake}

Potassium uptake by potato tuber and haulm influenced statistically significantly by different treatments (Table $1 \& 2$ ). The maximum potassium (539.40 $\mathrm{Kg} \mathrm{ha}^{-1}$ ) uptake by potato tuber was recorded where poultry manure was used in combination with inorganic fertilizer $\left(\mathrm{T}_{5}\right)$ and the minimum $(279.93 \mathrm{~kg}$ $\left.\mathrm{ha}^{-1}\right)$ recorded in case of conventional farming $\left(\mathrm{T}_{3}\right)$ (Table 2). The potassium uptake by potato haulm ranged from 15.22 to $42.04 \mathrm{~kg} \mathrm{ha}{ }^{1}$. The maximum (42.04 $\mathrm{Kg} \mathrm{ha}^{-1}$ ) was recorded in case of poultry manure treatment $\left(\mathrm{T}_{2}\right)$ and the minimum $(15.22 \mathrm{~kg} \mathrm{ha}$

$\left.{ }^{1}\right)$ was found where inorganic fertilizer $\left(\mathrm{T}_{2}\right)$ was used (Table 2). Jeegedeeswari et al. (2000) reported that K uptake in rice plant was higher in urban compost treated plot over green manure and controlled treatment.

\section{Calcium and Magnesium Uptake}

The results in the Table 1 and 2 indicated that there were significant variation in $\mathrm{Ca}$ and $\mathrm{Mg}$ uptake by tuber and haulm due to the effect of various treatments. The highest $\mathrm{Ca}\left(231.40 \mathrm{Kg} \mathrm{ha}^{-1}\right)$ uptake by potato tuber was recorded where cowdung $\left(\mathrm{T}_{1}\right)$ was applied separately and the minimum was (86.80 $\mathrm{Kg} \mathrm{ha}^{-1}$ ) recorded where inorganic fertilizer was used $\left(\mathrm{T}_{3}\right)$ (Table 1). This result might be due to the higher $\mathrm{Ca}$ content in tuber. Magnesium uptake by potato tuber ranged from 99.82 to $301.89 \mathrm{Kg} \mathrm{ha}^{-1}$. The maximum $\mathrm{Mg}$ (301.89 $\mathrm{kg} \mathrm{ha}^{-1}$ ) uptake by tuber was found where poultry manure $\left(\mathrm{T}_{2}\right)$ was used and the minimum $\left(99.82 \mathrm{~kg} \mathrm{ha}^{-1}\right)$ recorded where inorganic fertilizer $\left(\mathrm{T}_{3}\right)$ was used (Table 1$)$.

\section{Sulphur Uptake}

Different treatments brought a significant influence on sulphur uptake by tuber and haulm of potato (Table 1\& 2). The sulphur uptake by tuber ranged from 26.04 to $65.93 \mathrm{~kg} \mathrm{ha}^{-1}$. The poultry manure produced the highest $\mathrm{S}$ uptake of $65.93 \mathrm{~kg} \mathrm{ha}^{-1}\left(\mathrm{~T}_{2}\right)$ and the lowest $\left(26.04 \mathrm{Kg} \mathrm{ha}^{-1}\right)$ uptake was recorded in case of conventional farming $\left(\mathrm{T}_{3}\right)$ (Table 1).

Sulphur uptake of potato haulm ranged from 0.04 to $6.55 \mathrm{~kg} \mathrm{ha}^{-1}$. The maximum $\mathrm{S}$ uptake by haulm recorded where poultry manure $\left(\mathrm{T}_{2}\right)$ and the minimum was recorded in conventional farming $\left(\mathrm{T}_{3}\right)$ (Table 2$)$.

\section{Zinc Uptake}

Zinc uptake by tuber and haulm showed a significant variation for different treatments (Table 1 and 2). The highest tuber $\mathrm{Zn}\left(0.85 \mathrm{~kg} \mathrm{ha}^{-1}\right)$ uptake was recorded in poultry manure treated plot and the minimum was recorded in case of inorganic fertilizer $\left(\mathrm{T}_{3}\right)$ (Table 1). The $\mathrm{Zn}$ uptake by potato haulm ranged from 0.02 to $0.04 \mathrm{~kg} \mathrm{ha}^{-1}$. Poultry manure and poultry manure with inorganic fertilizer produced highest $\mathrm{Zn}$ uptake and the minimum was recorded in case of inorganic fertilizer (Table 2).

\section{Starch content of potato tuber}

The starch content of potato tuber has been presented in Table 3. It was seem that there were considerable effects of fertilizer treatments on the tuber starch content of potato. The starch content of potato tuber ranged from 55.81 to $76.93 \%$ due to different treatments effect. The highest starch content (76.93 $\%$ ) was recorded in the treatment treated with cowdung which was statistically identical to the treatment of poultry manure (T2) and lowest starch $(55.81 \%)$ content was found where inorganic fertilizer was used (T3).

\section{Protein content of potato tuber}

The result exhibited that protein content was significantly influenced due to different treatment (Table 3). The protein content of tuber ranged from 8.39 to $11.13 \%$. The highest protein content was observed in the treatment where cowdung (T1) was used alone and gave $(32.66 \%)$ higher protein content over conventional (T3). The ranged of increased percent of protein content over conventional farming (T3) was 7.37 to $32.66 \%$. However the highest percent increase $(32.66 \%)$ in protein content was observed where cowdung was used. Srikumar and Ockerman (1990) reported that crude protein content of potatoes influenced by organic manures (7.49 $8.16 \%$ ) over conventional (inorganic fertilizer).From the previous report it is clear that the combination of organic matter with conventional farming showed its superiority on yield and yield contributing characters of potato (Islam et al., 2008) but organic farming showed their superiority on nutrient contents and their uptake (Asumus and Gorlitz, 1980). 
Table 1. Effect of organic farming on $\mathrm{N}, \mathrm{P}, \mathrm{K}, \mathrm{Ca}, \mathrm{Mg}$ and $\mathrm{S}$ uptake by potato tuber

\begin{tabular}{|l|l|l|l|l|l|l|l|}
\hline \multirow{2}{*}{ Treatments } & \multicolumn{7}{|c|}{ Nutrient Uptake (kg ha1) of potato tuber } \\
\cline { 2 - 8 } & $\mathrm{N}$ & $\mathrm{P}$ & $\mathrm{K}$ & $\mathrm{Ca}$ & $\mathrm{Mg}$ & $\mathrm{S}$ & $\mathrm{Zn}$ \\
\hline T1 & $455.00 \mathrm{~b}$ & $122.2 \mathrm{c}$ & $465.40 \mathrm{~b}$ & $231.40 \mathrm{a}$ & $236.60 \mathrm{c}$ & $44.20 \mathrm{c}$ & $0.67 \mathrm{~b}$ \\
\hline T2 & $628.07 \mathrm{a}$ & $211.67 \mathrm{a}$ & $558.67 \mathrm{a}$ & $211.67 \mathrm{~b}$ & $301.89 \mathrm{a}$ & $65.93 \mathrm{a}$ & $0.85 \mathrm{a}$ \\
\hline T3 & $297.29 \mathrm{~d}$ & $71.61 \mathrm{~d}$ & $279.93 \mathrm{c}$ & $86.80 \mathrm{e}$ & $99.82 \mathrm{e}$ & $26.04 \mathrm{e}$ & $0.47 \mathrm{c}$ \\
\hline T4 & $393.10 \mathrm{c}$ & $114.30 \mathrm{c}$ & $426.56 \mathrm{~b}$ & $158.91 \mathrm{~d}$ & $203.52 \mathrm{~d}$ & $39.03 \mathrm{~d}$ & $0.66 \mathrm{~b}$ \\
\hline T5 & $6.28 .68 \mathrm{a}$ & $145.08 \mathrm{~b}$ & $539.40 \mathrm{a}$ & $182.28 \mathrm{c}$ & $255.43 \mathrm{~b}$ & $55.80 \mathrm{~b}$ & $0.88 \mathrm{a}$ \\
\hline LSD $(0.05)$ & 45.91 & 16.84 & 50.87 & 14.36 & 13.78 & 4.168 & 0.059 \\
\hline CV $(\%)$ & 5.08 & 6.37 & 5.95 & 4.38 & 3.34 & 4.78 & 3.55 \\
\hline
\end{tabular}

$\mathrm{T} 1=$ Cowdung, $\mathrm{T} 2=$ Poultry manure, $\mathrm{T} 3=$ Inorganic fertilizers $(\mathrm{N}+\mathrm{P}+\mathrm{K}), \mathrm{T} 4=$ Cowdung+Inorganic fertilizers $(\mathrm{N}+\mathrm{P}+\mathrm{K})$

$\mathrm{T} 5=$. Poultry manure+ Inorganic fertilizers $(\mathrm{N}+\mathrm{P}+\mathrm{K})$

. Figure(s) in a column having same letter do not differ significantly at 5\% level by DMRT.

Table 2. Effect of organic farming on $\mathrm{N}, \mathrm{P}, \mathrm{K}, \mathrm{Ca}, \mathrm{Mg}$ and $\mathrm{S}$ uptake by potato haulm

\begin{tabular}{|l|l|l|l|l|l|l|l|}
\hline \multirow{2}{*}{ Treatments } & \multicolumn{7}{|c|}{ Nutrient Uptake (kg ha1) of potato haulm } \\
\cline { 2 - 8 } & $\mathrm{N}$ & $\mathrm{P}$ & $\mathrm{K}$ & $\mathrm{Ca}$ & $\mathrm{Mg}$ & $\mathrm{S}$ & $\mathrm{Zn}$ \\
\hline T1 & $21.62 \mathrm{c}$ & $5.72 \mathrm{~b}$ & $35.40 \mathrm{bc}$ & $19.71 \mathrm{~b}$ & $18.86 \mathrm{a}$ & $4.45 \mathrm{c}$ & $0.03 \mathrm{~b}$ \\
\hline T2 & $39.03 \mathrm{a}$ & $8.74 \mathrm{a}$ & $42.04 \mathrm{a}$ & $23.75 \mathrm{a}$ & $18.56 \mathrm{a}$ & $6.55 \mathrm{a}$ & $0.04 \mathrm{a}$ \\
\hline T3 & $13.81 \mathrm{~d}$ & $2.67 \mathrm{c}$ & $15.22 \mathrm{~d}$ & $8.32 \mathrm{c}$ & $7.37 \mathrm{c}$ & $2.04 \mathrm{e}$ & $0.02 \mathrm{c}$ \\
\hline T4 & $25.48 \mathrm{~b}$ & $4.96 \mathrm{~b}$ & $32.80 \mathrm{c}$ & $19.11 \mathrm{~b}$ & $14.86 \mathrm{~b}$ & $3.54 \mathrm{~d}$ & $0.03 \mathrm{~b}$ \\
\hline T5 & $39.50 \mathrm{a}$ & $5.64 \mathrm{~b}$ & $38.02 \mathrm{~b}$ & $23.46 \mathrm{a}$ & $17.23 \mathrm{a}$ & $5.05 \mathrm{~b}$ & $0.04 \mathrm{a}$ \\
\hline LSD $(0.05)$ & 3.234 & 1.031 & 3.377 & 2.306 & 1.884 & 0.501 & 0.006 \\
\hline CV $(\%)$ & 6.16 & 9.88 & 5.47 & 6.49 & 6.51 & 6.16 & 6.17 \\
\hline
\end{tabular}

$\mathrm{T} 1=$ Cowdung, $\mathrm{T} 2=$ Poultry manure, $\mathrm{T} 3=$ Inorganic fertilizers $(\mathrm{N}+\mathrm{P}+\mathrm{K}), \mathrm{T} 4=$ Cowdung+Inorganic fertilizers $(\mathrm{N}+\mathrm{P}+\mathrm{K})$

$\mathrm{T} 5=$. Poultry manure+ Inorganic fertilizers $(\mathrm{N}+\mathrm{P}+\mathrm{K})$

Figure(s) in a column having same letter do not differ significantly at 5\% level by DMRT.

Table 3. Effect of organic farming on Starch and Protein content of potato tuber

\begin{tabular}{|c|c|c|}
\hline \multirow[t]{2}{*}{ Treatments } & \multicolumn{2}{|c|}{ Starch and Protein content (\%) of potato tuber } \\
\hline & Starch & Protein \\
\hline T1 & $76.93 \mathrm{a}$ & $11.13 \mathrm{a}$ \\
\hline $\mathrm{T} 2$ & $63.09 \mathrm{~b}$ & $10.71 \mathrm{a}$ \\
\hline T3 & $55.81 \mathrm{e}$ & $8.39 \mathrm{c}$ \\
\hline $\mathrm{T} 4$ & $60.51 \mathrm{c}$ & $10.45 \mathrm{ab}$ \\
\hline T5 & $59.03 \mathrm{~d}$ & $9.01 \mathrm{bc}$ \\
\hline $\operatorname{LSD}(0.05)$ & 2.464 & 1.450 \\
\hline $\mathrm{CV}(\%)$ & 2.07 & 7.75 \\
\hline
\end{tabular}

\section{References}

Asumus, F. 1983. effect of organic manuring on yield and organic matter content of sandy soils. Tagunsbericht, Akademic der Land wortschoff tswissen schaften der Deustshcen Demokrotischen Republic. 211:31-39 [Cited from Potato Abstr., 10(2):16,1985].

Brahmachari, K. and Mondal, S. S. 2000. Potassium and sulphur nutrition of crops with or without organic manure under Jute-rice-rape seeds sequence. Indian J. Agron., 45 (3): 501-507.

Drinkwater, L.; Dkletourneau, E.; Workneh, F.; Van Bruggen, A. H. C. and Shennan, C. 1995. Fundamental differences between conventional and organic tomato agrosystem in California. Ecol. Appl., 5:1098-1112. 
Gomez, K. A. and Gomez, A. K. 1984. Statistical procedures for Agricultural Research. $2^{\text {nd }}$ edn. John Wiley and Sons. New York. 207215.

Hunter, A. H. 1984. Soil Fertility Analytical Service in Bangladesh. Consultancy Report, BARC, Dhaka.

IFOAM (International Federation of Organic Agriculture Movements), 1996. Basic Standards for Organic Agriculture and Processing. Tholey-Theley.

Islam, M. R.; Nahar, B. S; Baten, M. A. 2008. Effects of organic farming on the growth parameters, yield and yield components of potato. J. Environ. Sci. \& Natural Resources, 1 (1): 13-18.

Jackson, M. Z. 1973. Soil Chemical Analysis, Practice Hall of India Private Limited. New Delhi, India.

Jeegadeeswari, P. V.; Kumar, P. S. S. and Kumaraswamy, K. 2000. Potassium balance and uptake in continuous cropping of rice in an Alfisol. Crop Res. Hisar., 22 (2): 194200.

Khurana, S. M. P. 1978. Higher to less values of International Son Potato Souvenir Central Potato Station, Jullunder, India.

Morrison, F. B. 1956. Feed and Feeding. 22nd edn. The Morrison Publishing Company. Ithaca, New York. USA. Chapter V. p.77.

Page, A. L.; Miller, R. H. and Keney, D. R. 1989. Methods of Soil Analysis. Part II, $2^{\text {nd }}$ edn.
Amer. Soc. Agron. Inc. Madison. Wiscomin, USA.

Power, J. F. and Doran, J. W. 1984. Nitrogen use in organic farming. P. 585-600. In Hauck, R. D. (edt.). Nitrogen in crop production. A. S. A. CSSA. And SSA. Madison. W. I.

Scow, K. M.; Somasco, O.; Gunapala, N.; Lau, S.; Benette, R.; Ferris, H.; Miller, R. and Shennan, C. 1994. Transition from conventional to low-input agriculture changes soil fertility and biology. Calif. Agric., 48(5):20-26.

Sengar, S. S.; Wade, L. J.; Baghel, S. S.; Singh, R. K. and Singh, G. 2000. Effect of nutrient management on rice in rainfed lowland of Southeast Madhya Pradesh. Indian J. Agron. 45 (2): 315-322.

Sharma, M. P.; Bali, S. V. and Gupta, D. K. 2000. Crop yield and properties of inception as influenced by residue management under rice-wheat cropping sequence. J. Indian Soc. Soil. Sci., 48 (3): 506-509.

Srikumar, T. S. and Ockerman, P. A. 1990. Effect of fertilization and manuring on the content of some nutrients in potato (var. Provita). Food Chemistry. 37 (1): 47-50. [Cited from potato Abstr. 15(1-5):161,1990].

Thomson, H. C. and Kelly, W. C. 1972. Vegetable crops ( $5^{\text {th }}$ Edn.). McGraw Hill book Co., New York. p.372. 